\section{WORKSHOP PERHITUNGAN HARGA POKOK PRODUKSI BAGI UMKM BINAAN PINBASMUI}

Henny Mulyati ${ }^{1}$, Adi Rizfal Efria di², Nurwati ${ }^{3}$

1) Akuntansi, Institut Teknologi dan Bisnis Ahmad Dahlan J akarta

2) Akuntansi, Institut Teknologi dan Bisnis Ahmad Dahlan J akarta

3) Akuntansi, Institut Teknologi dan Bisnis Ahmad Dahlan J a karta

*Corresponding a uthor Email : Henny_ml@yahoo.co.uk

Artic le history

Received : diisi oleh editor Revised : diisi oleh editor

Accepted : diisi oleh editor

*Corresponding a uthor Pilih penulis yang a kan menjadi korespond ensi author Email : c orresponding a uthor
Abstraksi

Pusat Inkubasi Bisnis Syariah - Majelis Ulama Indonesia (PINBAS MUI) dibentuk untuk mengeduka si pelaku bisnis UM KM berbasis syariah dimana kegiatan utamanya adalah memfasilitasi sertifikasi halal untuk produk makanan dan minuman roduksi rumahan. Sejak awal tahun 2019 ITB-AD menjalin kejasama dengan PIN-BAS MUI agar dapat bersinergi dalam memecahkan problematika dunia usaha UMKM, mendukung program pemerintah untuk pemberdaya $n$ UMKM di tana $h$ a ir. Kegiatan workshop perhitungan harga pokok produksi ditujukan untuk memberikan penguasaan kepada peserta dalam menghitung harga pokok produksi makanan dan minuman. Kegiatan terdini dari survey awal untuk mengidentifika si permasalahan yang diha dapi. Pemasalaha $n$ yang umumnya terjadi adalah kurangnya pemahaman terhadap biaya produksi dimana biaya produksi dipahami hanya terd iridaribiaya bahan ba ku sehingga terja di kesalahan dalam penentuan harga pokok produksi. Berda sarkan ma sala h tersebut, diselenggarakan kegiatan workshop diawali dengan melakukan pre-tes, penyampaian materi, kegiatan diskusi, latihan, pendampingan untuk memastikan bahwa peserta telah mampu menghitung harga pokok produksi serta pos-tes tentang pemahaman teori dan konsep harga pokok produksi. Berdasa rkan pendampingan dapat dipastikan bahwa peserta mampu menghitung harga pokok produksi dengan benar.

Keywords: UMKM, Harga Pokok Produksi

\begin{abstract}
Indonesian Ulema Council (MUI) created Central of Sharia Business Incubation (PINBAS) to give sharia education with the ma in ta rget facilita ting halal certific ation for the members. The members consist of businessmen who run small and medium enterprises (SME) in foods and beverages home ind ustry sec tor. In the beginning of year 2019, PINBAS-MUI a long with ITB-AD are doing some collaborations to solve the problems of these enterprises and to support the govemment for SME's empowement programs. One of the colaboration programs was doing workshop for food and beverages SME's industry which located around the campus of ITB-AD. The workshop a ims to give the participants about the knowledges of cost of production. The activities of the workshop sta rted with problems identifying. The problems identified generally are the lack of cost of production concepts. These lack of knowledges are especially beca use the term of cost wa sunderstood only for the cost of materials. They did not compute labors a nd overhead expenses as cost of product. Based on the problems, the workshop started by giving them the theory, demonstrations, exercises and accompaniment to ensure that the parcipants understood the contents. The results shown that the accompaniment efectifelly increase the capability of participants to count the cost of production correctly.
\end{abstract}

Keywords: The SME, Cost of Production 


\section{PENDAHULUAN}

\section{Latar Belakang}

Pusat Inkubasi Bisnis Syariah - Majelis Ulama Indonesia (PINBAS MUI) adalah suatu lembaga inkubator yang dibentuk oleh Majelis Ulama Indonesia (MUI) dengan tugas melakukan proses inkubasi terhadap peserta (tenant) yaitu : Usaha Mikro, Kecil, Menengah dan Koperasi (UMKMK).

Adapun tugasdan peran PINBASMUI a dalah :

a. Menyelenggarakan dan pengembangan program Inkubasi Wirausaha UMKMK.

b. Menumbuhkembangkan jiwa kewirausahaan, membuka lapangan kerja, mengentaskan kemiskinan, mengembangkan nilai tambah produk lokal yang halal \& daya saing daerah sehingga mampu memberikan kontribusi pada sistem ekonomi pasar.

c. Peningkatan Sumber Daya Manusia UMKMK mela lui proses Inkuba si bisnis Sya riah.

d. Mengembangkan UMKMK Potensial menjadi usaha mandin, sehing ga mampu dan sukses mengha dapi persainga $n$ lokal mapun global.

e. Mencanangkan Tahun 2019 sebagai Tahun Kebangkitan Produk Halal Umat Islam Ind onesia

f. Mendorong agar terciptanya pasar halal yang dicanangkan oleh Bupati atau Walikota setempat.

Terkait dengan proses inkubasi terhadap peserta (tenant), PINBAS MUI sebagai lembaga Inkubator berkewajiban mengajak, memfasilitasi, membina dan membimbing serta memampukan para pelaku usaha di level UMKM (Usaha Mikro, Kecil dan Menengah) sebagai subjek pebisnis yang mulai banyak diminati masyarakat di Indonesia.

Pelaku bisnis UMKM terdin dari industri rumah tangga yang menekuni kerajinan tangan, produksi dan penjualan makanan serta minuman, aneka fashion, a lat-alat kecantikan.

Pasal 4 UU No 20 Bab 3 Pasal 4 tentang Usaha Mikro, Kecil dan Menengah menyatakan bahwa tujuan pemberdayaan usaha mikro, kecil dan menengah adalah:

a. penumbuhan kemandirian, kebersamaan, dan kewirausahaan Usaha Mikro, Kecil, dan Menengah untuk berkarya dengan prakarsa sendir;

b. perwujudan kebijakan publik yang transparan, akunta bel, dan berkeadilan; c. pengembangan usaha berbasis potensi daerah dan berorientasi pasar sesuai dengan kompetensi Usaha Mikro, Kecil, dan Menengah;

d. peningkatan daya saing Usaha Mikro, Kecil, dan Menengah; dan

e. penyelenggaraan perencanaan, pelaksanaan, dan pengendalian secara terpadu.

Pada Pasal 4UU No 20 Bab 5 Pasal 7 tentang, penumbuhan iklim usaha adalah Dunia Usaha dan masyarakat berperan serta secara aktif membantu menumbuhkan Iklim Usaha sebaga imana dimaksud pada a yat (1).

Setiap tahun jumlah pelaku bisnis ini semakin bertambah dan tersebar di berbagai pelosok tanah air, yang membawa dampak kepada angka pengangguran di Indonesia semakin berkurang. UMKM juga menyumbang pertumbuhan ekonomi di Indonesia, dengan nilai mencapai $60 \%$.

Salah satu kelemahan Usaha Mikro, Kecil dan Menengah (UMKM) adalah belum tertatanya sistem manajemen usaha. Para pelaku UMKM biasanya menjalankan hampir semua urusan usahanya sendirian ata u dengan kekuatan yang serba terbatas. Seorang pengusaha kecil harus belanja bahan baku, mengerjakan produksi dan memasarkan sendiri hasil produknya. Ba nya knya pekerjaan yang harus dilakukan pelaku UMKM membuat volume produksi sering tidak konsisten, kualitas produk tidak terkontrol dan hanya berkutat pada wilayah pemasaran yang terbatas.

ITB-AD sebaga i Pergurua n Tinggi yang memiliki peran dalam melaksanaka $n$ Trid ha rma Perguruan Tinggi, menginisiasi kerjasama dengan PINBAS MUl. Kerjasama ini secara resmi dimulai pada awal tahun 2019. Melalui kerjasama antara PINBAS MUI dan ITB-AD, ITB Ahmad Dahlan Jakarta berperan serta dalam mengatasi dan melakukan pembinaan melalui program pengabdian kepada masyarakat (abdimas) yang merupakan bagian dari tri dhama Perguruan Tinggi sebagai mana diatur dalam Undang - undang Nomor 12 Tahun 2012 tentang Perguruan Tinggi..

Tujuan abdimas untuk memajukan kesejahteraan umum dan mencerdaskan kehidupan bangsa melalui peningkatan peran UMKM dalam pengembangan kegiatan 
usahanya. Pengabdian kepada masyarakat ini merupakan kegiatan civitas akademika dalam mengamalkan dan membudayakan ilmu pengetahuan dan teknologi melalui kegiatan pelatihan Perhitungan Harga Pokok Produksi.

Berdasarkan survey awal yang dilakukan terhadap UMKM dibawah naungan PINBAS MUI terdapat berbagai jenis home industri yang membutuhkan pendampingan agar dapat berkembangan. Mayoritas UMKM bergerak dalam bidang produksi dan penjualan makanan dan minuman ringan sebanyak 54 UMKM DARI 208 UMKM. Analisis situasi terhadap UMKM jenis industri ini adalah mengenai kemampuan yang masih rendah terha dap perhitunga $n$ harga pokok produksi. Kemampuan yang rendah ditunjukkan dengan cara perhitungan sederhana tanpa didasari oleh pengetahuan secara teori yang diperlukan sebagai dasar perhitungan. Konsep biaya overhea d pabrik yang belum dikua sai a ka n menyebabkan kesulitan pembebanan BOP terhadap produk yang akan berpengaruh terha dap keakuratan hasil perhitungan HPP.

\section{Rumusan Masalah}

Dari uraian diatas dirumuskan permasalahan yang terjadipada UMKM sebagai berikut:

a. Pelaku usaha UMKM tidak memahami konsep biaya produksi

b. Pelaku usaha UMKM tidak memiliki dasar pengetahuan yang cukup tentang pembebanan biaya produksi tidak langsung

c. Perhitungan harga pokok produksi tidak dilakukan secara benar

\section{Tujuan}

Tujuan Kegiatan workshop perhitunga n harga pokok produksi berdasarkan metode full costing kepada umkm dibawah binaan PINBAS MiUl adalah sebagai berikut :

a. Memberikan pengenalan terhadap konsep biaya produksi

b. Memberikan penjelasan dan pelatihan terhadap pembebanan biaya produksi tidak langsung

c. Memberikan pendampingan terhadap perhitungan biaya produksi secara benar

\section{TINJ AUAN PUSTAKA}

\section{Pengertian akuntansi biaya}

Menurut Mulyadi (2016), a kuntansi biaya adalah proses pencatatan, penggolongan, peringkasan dan penyajian bia ya, pembuatan dan penjuala $n$ produk atau jasa, dengan cara-cara tertentu, serta penafsiran terhadap hasilnya. Akuntansi biaya sebagai bentuk pertanggungjawaban sekaligus membantu pihak pengguna untuk mengetahui jumlah biaya produksi yang berguna dalam pengambilan keputusan. Mulyadi (2016) juga menjela skan tujuan a kuntansi biaya sebagai berikut :

1. Penentuan kosproduk

2. Pengendalian biaya, dan

3. Pengambilan keputusan khusus

\section{Eemen Biaya Produksi}

Biaya produksi terdiri dari Biaya Bahan langsung, Biaya tenaga kerja langsung dan biaya overhead pabrik.

Menurut Dunia et al (2014) “Bahan langsung merupakan biaya perolehan dari seluruh bahan langsung yang menjadi bagian yang integral yang membentuk barang jadi (finished good), misalnya kayu yang dipakai untuk membuat meja dan kursi".

Menurut Dunia et al (2014) “ Biaya overhead pabrik adalah semua biaya untuk memproduks suatu produk selain dari bahan langsung dan tenaga kerja langsung. Biaya ini lebih ja uh dapat dikla sifika sika n ke dalam tiga unsur pokok:

- Bahan tidak langsung

- Biaya tenaga kerja tidak langsung

- Biaya produksi tidak lansung lainnya, seperti: asuransi peralatan pabrik, penyusutan peralatan pabrik dan lain-lain".

\section{Biaya Overhead Pabrik (BOP)}

Biaya overhead pabrik adalah biaya produksi yang pada umumnya memiliki sifat tidak langsung terhadap pembentukan produk jadi. BOP sulit untuk ditelusuri secara langsung sehingga membutuhkan metode tertentu dalam pembebanannya terhadap unit cost.

Dalam melakukan pembebanan diperlukan tarif yang menjadi dasar pembebanannya. Berikut adalah dasarpenentuan tarif :

1) Satuan Produk

Rumus untuk menghitung tarif BOP adalah dengan membagi jumlah BOP yang dianggarkan selama satu periode dengan jumlah produksi yang dihasulkan. Metode ini cocok untuk digunakan oleh unit usaha yang ha nya mengha silkan sa tu macam produk.

2) Biaya Bahan Langsung

Rumus tariff menggunakan bahan langsung adalah dengan membagi BOP yang dianggarkan selama satu periode dengan jumlah biaya bahan langsung dalam periode yang sama kemudian dikalikan $100 \%$. Hasilnya berupa tariff dengan persentase. Semakin besar bahan baku yang digunakan dalam menghasilkan produk maka semakin besar jumlah biaya overhead pabrik yang dibebankan 
3) Biaya Tenaga Kerja Langsung

Rumustariff mengguna kan biaya tenaga kerja langsung juga menghasilkan tariff dengan bentuk persentase. Rumus yang digunakan adalah dengan membagi jumlah BOP dalam satu periode dengan jumlah biaya tenaga keja langsung dalam satu periode dikalikan dengan $100 \%$. Semakin besar biaya tenaga keja yang dibebankan maka semakin besar jumlah BOP

4) J umlah jam mesin

Rumus ini digunakan bila unit usaha menggunakan mesin sebagai alat produksi yang dominan. Semakin lama penggunaan mesin dalam proses produksi maka semakin besar jumlah BOP yang dibebankan. Tarif dihitung dengan membagi jumlah BOP yang dianggarkan dengan jumlah jam mesin yang diperkirakan terpaka i periode yang sama. Ta rif yang dihasilkan a dalah perjam mesin.

5) J umlah jam tenaga kerja.

Bila jam tenaga keja adalah factor dominan dalam menghasilkan produk maka dasarjam tenaga keja digunakan dalam penentuan tariff. Semakin lama proses produksi dalam satuan jam, maka semakin besar biaya overhead pabrik. Tarif dihitung dengan mebagi jumlah BOP dalam satu periode dengan jumlah jam tenaga keja langsung yang direncanakan akan dikonsumsi dalam menghasilkan produk dalam satu tahun anggaran. Hasil yang diperoleh adalah tariff perjam tenaga kerja.

\section{Manfaat Harga Pokok Produksi}

Mulyadi (2016) menyatakan bahwa: "manfaat informasi harga pokok produks yaitu: menentukan harga jual produk, memantau realisasi biaya produksi, menghitung laba atau rugi periodik, menentukan harga pokok persediaan produk jadi dan produk da lam proses yang disajikan dalam neraca".

\section{Metode dalam penentuan Harga Pokok Produksi}

Metode penentuan harga pokok produksi terbagi dua yaitu :

\section{a. Metode full costing, dan \\ b. Metode variable costing}

Berikut diuraikan penjelas ke dua metode tersebut:

\section{a) Metode Full Costing}

Metode ini menghitung harga pokok produks yang terdiri dari unsur bia ya variable dan unsur biaya tetap dalam proses produksi. Biaya produksi terdin dari :

1. Biaya bahan baku langsung

2. Biaya Tenaga Kerja Langsung

3. BOP tetap dan BOP Variabel

Total harga pokok produksi pada metode ini adalah dengan menjumlahkan harga pokok produksi dan biaya non produksi yang terdin dari biaya administrasi\&umum dan Blaya pemasaran

Metode full costing adalah metode yang diterima dalam penyusunan laporan keuangan untuk ekstemal perusahaan. Fomat yang disajikan dalam metode ini sesuai dengan format yang dibutuhkan dalam akuntansi keuangan untuk pelaporan ekstemal perusahaan.

\section{b) Metode Variabel costing}

Metode variable costing menggunakan biaya variable sebagai unsur utama biaya produksi yang terdiri dari biaya bahan baku langsung, biaya tenaga keja langsung dan BOP variable. BOP tetap dan biaya tetap lainnya dikelompokkan ke dalam biaya periode. Sementara biaya adminsitrasi\&umum serta bia ya pemasaran variable menjadi total unsur biaya variable dalam menghitung margin kontribusi atau;

Margin Kontribusi = Penjualan - Total Blaya Variabel (Biaya Produksi +Non Produksi Variabel)

Format ini biasanya digunakan oleh pihak intemal perusahaan dalam menjalankan fungsi manajemen terutama dalam pengambilan keputusan khusus dan memerlukan penyesuaian bila diperlukan untuk tujua n pela poran ekstemal.

\section{METODE PENEUTIAN}

\section{Objek Penelitian}

Peserta workshop terdin dari 8 UMKM yang melakukan usaha pada produksi makanan dan minuman dan memasa rkan di wilaya $h$ Tangerang Selatan yaitu Ciputat dan Pamulang. Jenis produksi makanan dari UMKM peserta workshop adalah ayam bakar (usaha katering), asinan buah, rempeyek, kue kering dan minuman kopi (kafe).

\section{Proses pengumpulan data}

Proses pengumpulan data dilakukan dengan menggunakan tahapan sebagai berikut: 
1. Survey Lapangan

Menupakan survey awal yang dilakukan terhadap sasaran atau target peserta workshop dengan melakukan:

a. Identifikasi masalah yang dilakukan sebagai langkah awal dalam menumuskan materi yang akan disampaikan

b. Melakukan pendataan peserta sasaran pelatihan

2. Penelitian pustaka yang digunakan sebagai acuan dalam menjalankan pelatihan

3. Metode Kegiatan Pelatihan

Kegiatan lebih banyak kepada peningkatan ketra mpilan yaitu terdiri dari

a. Metode ceramah untuk menjelaskan secara teori tentang biaya dan metode perhitungan harga pokok produksi

b. Metode simulasi untuk menjelaskan perhitungan harga pokok produksi dengan menggunakan metode ha rga pokok full costing

c. Metode demonstrasi untuk mempraktekkan cara menghitung harga pokok produks mitra umkm peserta pelatihan.

d. Metode pendampingan untuk mengetahui secara langsung kemampuan peserta workshop dalam menghitung harga pokok produksi serta membantu memecahkan masalah yang dihadapi peserta.

\section{Evaluasi Program}

\section{Pelaksanaan Pre test dan post test}

Tujuan untuk mengetahui perbedaan pemahaman peserta sebelum dan sesudah mengikuti kegiatan workshop.

\section{PEMBAHASAN}

Kegiatan pengabdian kepada masyarakat melalui kegia ta n workshop kepada pelaku UM KM seperti diuraikan pada sub bab metode sebelumnya diawali dengan survey berdasarkan pendataan calon peserta UMKM yang dipilih di wilayah Ciputat dan Pamulang, kota Tangerang Selatan. Pemilihan UM KM berdasarkan wilayah ini dilakukan untuk menjangkau UMKM yang terdekat agar ITB AD memberikan kontribusi pengembangan UMKM di wilayah sekitar kampus. Pemilihan peserta juga difokuskan kepada UMKM yang bergerak sebagai penghasil dan penjual makanan. Peserta terdiri da ri 8 UM KM yang merupakan binaan PINBASMUI.

Berikut Daftar Peserta workshop beserta jenis usa hanya

Tabel 1. Daftar Peserta Workshop dan J enis Usahanya

\begin{tabular}{|l|l|l|l|}
\hline NO & $\begin{array}{l}\text { Nama } \\
\text { Usaha }\end{array}$ & $\begin{array}{l}\text { Jenis } \\
\text { Usaha }\end{array}$ & Produk \\
\hline 1 & $\begin{array}{l}\text { Kuca } \\
\text { Kaffe }\end{array}$ & Kuliner & $\begin{array}{l}\text { Kopi Bubuk, } \\
\text { Kopi Susu Botol }\end{array}$ \\
\hline 2 & $\begin{array}{l}\text { Andila's } \\
\text { Cookies }\end{array}$ & Kuliner & Kue Kering \\
\hline 3 & $\begin{array}{l}\text { Nesya } \\
\text { Shop }\end{array}$ & $\begin{array}{l}\text { Obat } \\
\text { herbal }\end{array}$ & Black Garlik \\
\hline 4 & $\begin{array}{l}\text { Uma } \\
\text { Snack }\end{array}$ & Kuliner & $\begin{array}{l}\text { Kacang } \\
\text { Bawang }\end{array}$ \\
\hline 5 & $\begin{array}{l}\text { Pecel } \\
\text { Suroboyo }\end{array}$ & Kuliner & Rempeyek \\
\hline 6 & $\begin{array}{l}\text { Asinan } \\
\text { Ima }\end{array}$ & Kuliner & Asinan Buah \\
\hline 7 & $\begin{array}{l}\text { Dapoer } \\
\text { Endes }\end{array}$ & Kuliner & $\begin{array}{l}\text { Makanan } \\
\text { Catering } \\
\text { Makanan } \\
\text { Catering }\end{array}$ \\
\hline 8 & $\begin{array}{l}\text { Ina } \\
\text { Catering }\end{array}$ & Kuliner & \multicolumn{2}{|l}{} \\
\hline
\end{tabular}

Berikut ini adalah gambar contoh produk yang dihasilka n oleh salah satu peserta workshop yaitu Nesya Shop yang memproduksi dan mema sarkan produk herbal yaitu Black Garlik yang dipasarkan melalui media online

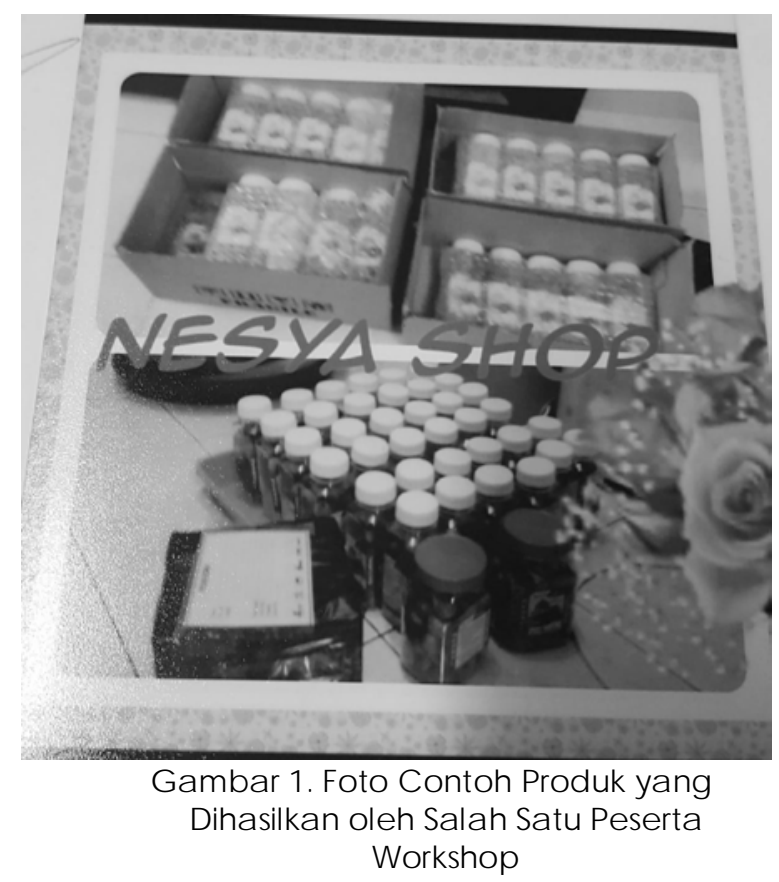

Dari survey awal yang dilakukan diketahui pada umumnya UMKM menghitung harga pokok produksi tanpa memasukkan unsur bia ya tenaga kerja langsung dan biaya overhead. Hal ini 
menunjukkan tidak akuratnya perhitungan harga pokok produksi yang berdampak pada penentuan harga jual dan perhitungan laba rugi UKMK.

Dari perumusan masalah yang berhasil diidentifika si, tim mempersiapkan materi dengan kajian pustaka sebagai bahan atau materi yang disampaikan pada acara workshop. Tinjauan pustaka terdiri dari konsep biaya, penggolongan biaya, elemen biaya produksi, metode penentuan harga pokok produksi fullcosting dan variable costing serta pembebanan biaya overhead pabrik.

Kegiatan workshop diawali dengan pre-tes yang merupakan upaya untuk mengetahui kemampuan atau pemahaman peserta workshop sebelum mengikuti workshop. Pertanyaan diajukan dalam bentuk multiple choice yang terdiri dari soal teori dan hitungan dengan jumlah soal 12 butir pertanyaan. J umlah pertanyaan ini dianggap memadai disesuaikan dengan tujuan workshop dan batasan waktu kegiatan.

Kegiatan selanjutnya adalah penyampaian materi yang mencakup :

a. konsep biaya dan perhitungan harga pokok produksi serta

b. simulasi perhitungan harga pokok produksi dengan memberikan contoh ilustrasi kasus pada usaha produksi roti manis.

Dalam sesi penyampaian materi, diberikan kesempatan tanya jawab dan diskusi tentang kesulitan dari perhitungan harga pokok produksi. Pertanyaan umumnya tentang pembebanan biaya overhead pabrik karena karakter biaya ini adalah tidak langsung dan sulit untuk tentukan dalam perhitungan harga pokok produksi. Diskusi menjadi menarik karena masing-masing peserta memiliki jenis biaya overhead yang berbeda dan sebelumnya tidak pemah memasukkan kompenen biaya overhead dalam perhitungan harga pokok produksi.

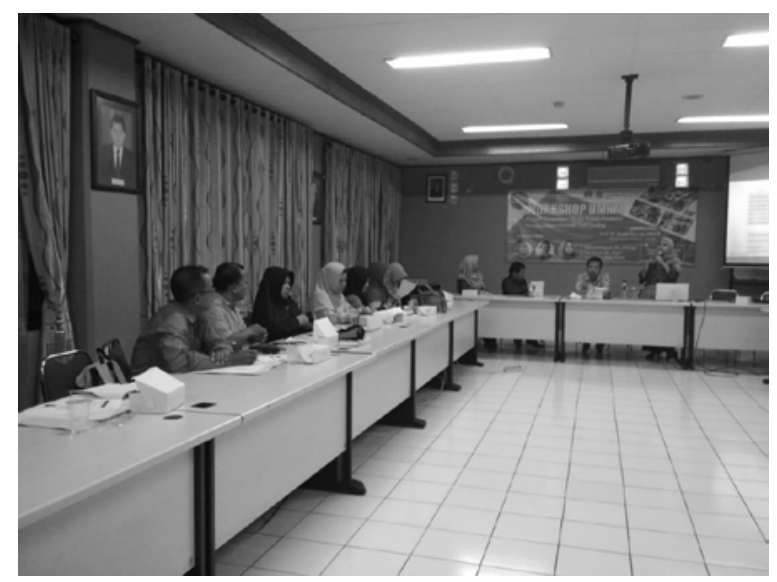

Gambar2. Foto Peserta mengikuti sesi penya mpaian materi workshop.

Peserta kemudian diberikan waktu latihan dengan mengisi formulir perhitungan harga pokok produksi dengan menggunakan data biaya produksi yang dimiliki oleh masing-masing unit usa ha nya.

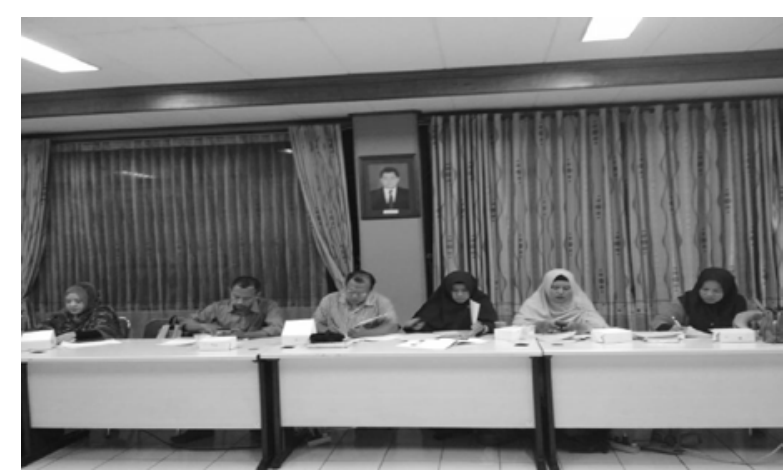

Gambar 3. Foto peserta mengerjakan latihan perhitungan harga pokok produksi

Pada saat latihan peserta yang telah menyelesaikan tugas diberi kesempatan untuk berkonsultasi dengan nara sumber. Nara sumber memberikan pendampingan kepada peserta dengan membimbing secara langsung. Melalui pembimbingan ini peserta dapat mendiskusikan masalah yang dihadapi bersama nara sumber. Nara sumber sekaligus dapat mengeta hui sejauh mana penguasaan peserta dalam perhitungan biaya produksi. Melalui kegiatan pendampingan ini juga dapat dipastikan bahwa masing-masing peserta telah mampu menerapkan perhitungan harga pokok produksi untuk produk yang diha silka nnya berdasarkan teori yang a da.

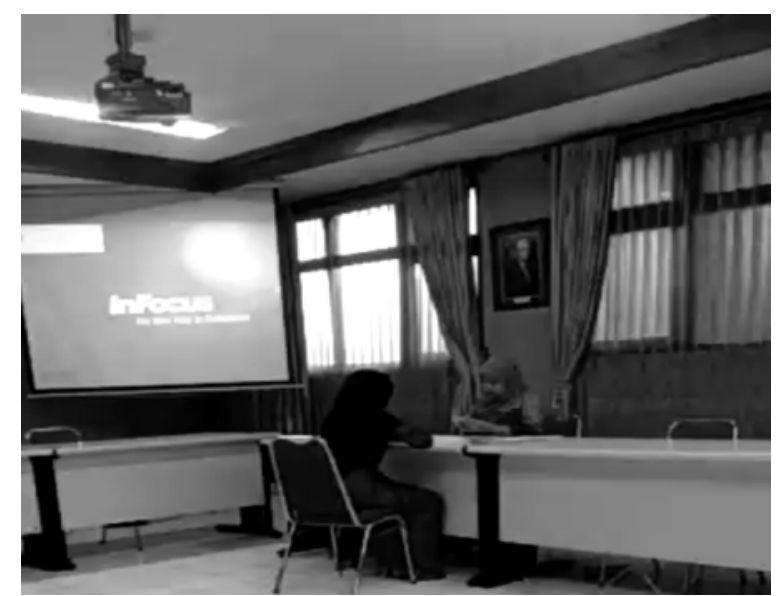

Gambar 4. Foto Peserta berkonsultasi setelah menyelesa ikan tugas perhitungan harga pokok produksi (pendampingan)

Setelah pendampingan kegiatan dilanjutkan dengan memberikan soal (postes) untuk mengetahui apakah terjadi perbedaan 
signifikan pemahaman terhadap teori akuntansi biaya sebelum dan sesudah peserta mengikuti kegiatan workshop.

Hasil pre-test dan post-test diuji dengan menggunakan analisis wilcoxon Rank Sum Test yang disajikan da lam tabel 2.

Acara diakhin dengan pemberian sertifikat secara simbolik kepada salah satu peserta workshop.

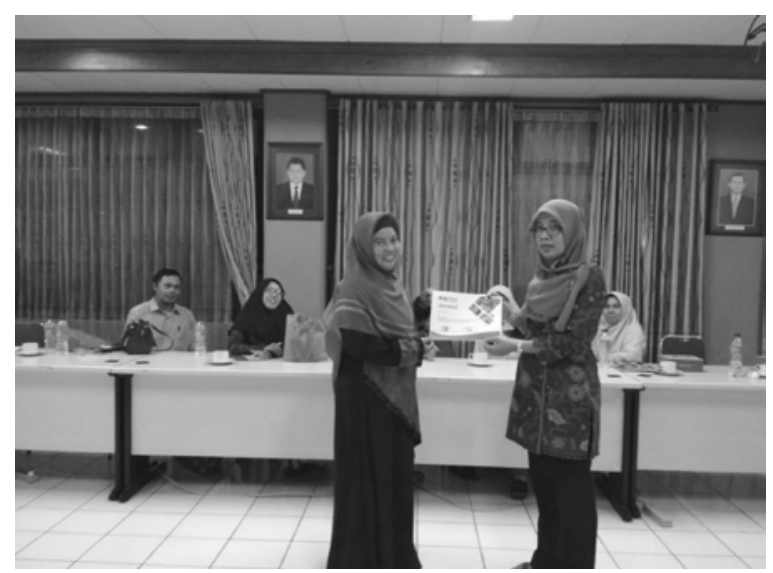

Gambar 5. Foto Penyerahan sertifikat pelatiha n kepada peserta

\begin{tabular}{|c|c|c|c|}
\hline 42 & 68 & 3 & 3,5 \\
\hline 50 & 75 & 5 & 6 \\
\hline \multirow[t]{2}{*}{44,75} & 70 & 36 & 36 \\
\hline & A & B & \\
\hline $\begin{array}{l}\text { count } \\
\text { rank }\end{array}$ & 8 & 8 & \\
\hline sum & 36 & 36 & \\
\hline
\end{tabular}

\begin{tabular}{l|r|} 
a & 0,05 \\
tails & 2 \\
W & 36 \\
W-crit & 451 \\
sig & yes \\
\hline
\end{tabular}

Hasil uji statistik dengan wilcoxon Rank Sum Test, menunjukkan adanya perbedaan signifikan pemahaman peserta sebelum dan sesudah pelatihan tentang harga pokok produksi dimana nilai Whitung kurang dari nilai W-crit artinya terdapat perbedaan yang signifikan mengenai pemahaman peserta workshop sebelum dan sesudah kegiatan.

\section{SIMPULAN, KEIERBATASAN DAN IMPUKAS}

\section{Simpulan}

Workshop perhitungan harga pokok produksi diawali dengan survey lapangan untuk mengidentifikasi masalah yang terjadi UMKM yang bergerak dalam usaha produksi dan penjualan makanan dan minuman dibawah binaan PINBAS dengan lokasi Ciputat dan Pamulang. Hasil survey menunjukkan kelemahan secara umum calon peserta workshop pada perhitungan harga pokok dimana biaya produks hanya dihitung dari biaya bahan baku yang dikeluarkan untuk menghasilkan makanan dan minuman. Pemahaman ini dilatarbelakangi kekeliruan konsep biaya yang hanya terbatas pada biaya pembelian dari bahan baku yang digunakan. Hasil workshop menunjukkan a danya perbedaan yang signifikan sebelum dan sesuda $h$ dilaksanakannya kegiatan dimana terjadiu peningkatan yang signifikan terhadap pemahaman biaya produksi. Kegiatan workshop juga dilengkapi dengan upaya pendampuingan untuk memastikan setiap peser workshop mampu menghitung biaya produksi berdasarkan teori dengan menggun\&kan data $\beta$ rpduksi masing-masing peserta. 36 36 Kerja sama PINBAS-MUI dengan ITB-AD perlu terus dilanjutkan pada aktifitas yang sama maupun pada progas lainnya. Kegiatan workshop perhitungan harga pokok produksi ini perlu diperluas dengan cak kupan wilayah yang 
meliputi Jabodetabek. Perlu juga diupayakan keberlanjutannya dengan pemberian materi penggunaan informasi harga pokok produksi untuk tujua n pengendalian biaya dan penentua $n$ harga jual produkyang berguna bagi para UMKM dalam menjalankan usahanya.

\section{Keterbatasan}

Pengabdian kepada Masyarakat melalui kegiatan workshop ini memiliki keterbatasan pada waktu pelaksanaan. Berdasarkan rencana yang disusun workshop perhitungan harga pokok produksi memiliki 15 target peserta. Jumlah ini ditetapkan dengan tujuan efektifitas pwnyelenggaraan workshop. Dalam hal ini nara sumber dianggap memilki cukup waktu untuk menyampaikan materi sekaligus pendampingan sa mpa i peserta da poat menera pka n materi yang diberikan. Dari jumlah yang diundang, tidak semua peserta berkesempatan hadir karena kendala aktifitas bisnis yang tak dapat ditinggalkan.

\section{Implikasi}

Kegiatan workshop ini memberikan pemahaman yang jelas bagi peserta disamping memberikan kemampuan menghitung harga pokok produksi berdasarkan teori dan konsep perhitungan yang benar. Perhitungan harga pokok produksi yang benar memungkinkan pelaku usaha mampu merencanakan dan mengendalikan biaya produksinya sehingga dapat bekerja secara efisien dalam menghasilkan produk. Unsur biaya produksi adalah komponen utama dalam penentuan harga jual nomal. Dengan demikian pelaku usaha juga dapat menetapkan harga jual dengan mempertimbangkan biaya dan laba yang diharapkan.

\section{PUSTAKA}

Dunia, Firdaus Ahmad. dan Abdullah, Wasilah., 2014, Akuntansi Biaya, Edisi 3, Jakarta: Salemba Empat.

Mulyadi., 2016, Akuntansi Biaya. Edisi 5, Cetakan 11, Yogyakarta: Sekolah Tinggi Ilmu Manajemen YKPN.

Republika.co.id, 13 Agustus, 2016, MUI bentuk 7 Pusat Inkubasi Bisnis Syariah, (On Line), (http://www.www.republika.co.id. diakses 20 Januari 2019) .

Undang-undang Republik Indonesia Nomor 20 Tahun 2008 tentang Usaha Mikro Kecil dan Menengah. 